Jap. J. Leprosy 47, 4 (1978)

\title{
Fundamental Studies on the Metabolism of Rifampicin (RFP)
}

\author{
MASAICHI GIDOH,* Yoshiki SAKAMOTO,* SADAE TSUTSUMI,* \\ and HIDEO NAKAGAWA** \\ (*National Institute for Loprosy Research) \\ (**Tokyo National Chest Hospital)
}

(Received for Publication, June 29, 1978)

Introduction of Rifampicin (RFP) into leprosy field has brought about a marked improvement to the clinical treatment of leprosy. This drug as a simple antimycobacterial substance can be distinguished from DDS which possesses several anti-inflammatory actions as already published previously ${ }^{1)}$. As was mentioned in the precedent general view ${ }^{21}$, this drug belongs to a sort of long-acting antibiotics through its entero-hepatic circulation as in the case of Novobiocin. Hereon, the long-term preservation of whole body distribution expressed generally by action area is an important factor for the systemic infectious diseases such as leprosy.

The inactivation of a drug under the in vivo metabolism can be classified into two, that is, the conjugation and the change in the skeleton causal to its efficacy. In the former case the efficacy of the drug can be recovered by the reversible demasking while it is real inactivation in the latter. In the case of RFP, the in vitro effects of its main metabolites such as desacetyl RFP (DARFP) and the quinone form (RFPQ) are known to be nearly comparable to that of RFP itself. In order to presume the in vivo preservation of RFP activity, the metabolism of each RFP metabolite was individually examined by the use of tracer method.

\section{Materials and Methods}

1. Synthesis of standard materials. Half a $\mathrm{mCi}$ of ${ }^{14} \mathrm{C}-\mathrm{RFP}\left({ }^{14} \mathrm{C}-\mathrm{CH}=\right.$ aminomethylpiperazinyl, $2.7 \mathrm{mCi} / \mathrm{mM}$. $3.28 \mu \mathrm{Ci} / \mathrm{mg}$ ) was kindly supplied by Daiichi Pharm. Co.

${ }^{14} \mathrm{C}$-DARFP and ${ }^{14} \mathrm{C}-\mathrm{RFPQ}$; According to the authentic method summarized in the precedent general view, ${ }^{1 \prime}$ these were synthesized and purified on buffered silica plate of $2 \mathrm{~mm}$ thickness. Each standard material showed single sharp peak radiochemically, pigmentally, and by UV-irradiation after developed on TLC plate with $\mathrm{CHCl}_{3}-\mathrm{MeOH}(9: 1)$ or $\mathrm{Me}_{2} \mathrm{CO}$. Sp. Act., DARFP, $2.2 \mathrm{mCi} / \mathrm{mM}$; RFPQ, $1.4 \mathrm{mCi} / \mathrm{mM}$.

${ }^{14} \mathrm{C}$-formyl RFP (RM-AF): When RFP is hydrolyzed under acidic side by the authentic method (in $0.1 \mathrm{~N} \mathrm{HCl}-0.1 \mathrm{M}$ Na-citrate, $\mathrm{pH} 2.2$ at $90^{\circ} \mathrm{C}$ for $4-6 \mathrm{hrs}$ ), numerous pigmental belts are seen on TLC plate bufferered at $\mathrm{pH}$ 6.0. Since the adsorption of RM-AF on the silica powder is so tight that it is difficult to extract $\mathrm{RM}-\mathrm{AF}$ with $\mathrm{CHCl}_{3}$. Therefore, the crude reaction mixture after hydrolysis was extracted with $\mathrm{CHCl}_{3}$ and it was once adsorbed on silica powder. The powder was repeatedly washed with $\mathrm{CHCl}_{3}$ to eliminate unchanged 
RFP and the other side-products. Then, powder was extracted with EtOH and evaporated rapidly below $40^{\circ} \mathrm{C}$ because $\mathrm{CHO}$ radical of RM-AF changes into its diethylacetal within 3 hrs. Thus, RM-AF of single peak could be isolated.

RFP-4-0-adamantane carboxylate (ADP) : Caused by the following reasons this substance was synthesized. a) to avoid the rapid oxidation of RFP to RFPQ, b) to increase further the liposolubility of RFP, c) to presume stereochemically the position of glucuronide conjugation..$^{3)}$ 1-adamantyl chloride ( $\mathrm{AdCl}, 50 \mathrm{mg}$, ca $250 \mu \mathrm{M}$, Tokyo Kasei Co.) was dissolved in $1 \mathrm{ml}$ of ice-cold pyridine. To this, a solution of ${ }^{14} \mathrm{C}-\mathrm{RFP}(42 \mathrm{mg}$, ca $50 \mu \mathrm{M}, 135 \mu \mathrm{Ci}$ dissolved in $3 \mathrm{ml}$ of pyridine-benzene $(1: 1)$ including $10 \mathrm{mg}$ of ascorbic acid and one drop of $1 \% \mathrm{~N}$-methy $\mathrm{N}^{\prime}$-aminopiperazine) was dropwisely added and kept for $2.5 \mathrm{hrs}$. at $5^{\circ} \mathrm{C}$. It was diluted with $10 \mathrm{ml}$ of $\mathrm{CHCl}_{3}$ and repeatedly washed with $0.1 \mathrm{M}$ phosphate, $\mathrm{pH}$ 7.0. The solvent was evaporated below $40^{\circ} \mathrm{C}$ and the residue was dissolved into small volume of $\mathrm{CHCl}_{3}$ and developed on a silica plate (Kieselgel, thickness $2 \mathrm{~mm}$, buffered with phosphate, $\mathrm{pH}$ 6.5) with $\mathrm{CHCl}_{3}$-benzene $(5: 3)$.

Five pigmental belts were separately detected, Rf 0.92 yellow and slight, Rf 0.79 orange and slight, $\mathrm{Rf} 0.58$ orange and very thick, $\mathrm{Rf} 0.33$ violet and slight, and $\mathrm{Rf} 0.25$ reddish and slight. The third main pigmental belt was scraped off and extracted with $\mathrm{CHCl}_{3}$. After evaporation of $\mathrm{CHCl}_{3}$ in vacuo, it remained yellow orange powder. It showed $\mathrm{Rf}$ value of 0.76 when developed with $\mathrm{n}-\mathrm{PrOH}-\mathrm{CHCl}_{3}$-Dioxane $(1: 3: 1)$ saturated with $0.1 \mathrm{M}$ phosphate, $\mathrm{pH}$ 6.5. While $\mathrm{Rf}$ values of the other standard materials were as follows: RFPQ, 0.66; DARFP-quinone (DARFPQ, synthesized from DARFP chromatographically), 0.54 ; RFP, 0.41; DARFP, 0.26. Sp. Act., $0.96 \mathrm{mCi} / \mathrm{mM}$. Similarly, by the use of nonlabeled RFP, non-labeled standard of ADP was synthesized. Since the reaction scale was larger than that of labeled case, the purification on TLC plate was repeated two times. Yellow orange needles, mp $171-174^{\circ} \mathrm{C}$ (decomp.). Anal. Calcd. for $\mathrm{C}_{54} \mathrm{H}_{72} \mathrm{~N}_{5} \mathrm{O}_{13}: \mathrm{C} \%, 65.83$; $\mathrm{H} \%, 7.36 ; \mathrm{N} \%, 5.68$. Found; $\mathrm{C} \%, 66.20 ; \mathrm{H} \% 7.70 ; \mathrm{N} \%, 5.02$.

Except the lack of $4-\mathrm{OH}$ peak, the NMR, spectrum of ADP was resemble to that of RFP as shown in Fig. 1.

2. Whole body autoradiography(WBARG). Five $\mu \mathrm{Ci}$ of each standard material suspended in Tween $80-\mathrm{CMCNa} / 5 \% \mathrm{EtOH}$ was dosed orally to mice by catheter and the mice were timewisely sacrificed by freezing after ether anesthesia. Each whole body slice of $40 \mu$ thickness by Auto-Cryotome NA 200F was dried and contacted with Fuji IX covering a period of 6 weeks. On the other side, $2 \mu \mathrm{Ci}$ of RFP was intramuscularly injected to Wistar rat in order to analyze the urinary RFP-glucuronide (RFPG). After the collection of urine for 4 hrs., the rat was sacrificed and the slices were contacted for 4 weeks.

3. Radiochemical analysis. The biological materials to be analyzed are picked out from residual frozen blocks and homogenized with 5-20 fold volumes of $60 \% \mathrm{MeOH} / 0.05 \mathrm{M}$ phosphate buffer, $\mathrm{pH} 7.0$ and centrifuged at $6900 \times \mathrm{G}$ for 15 mins. A portion of the supernatant was mixed with Bray scintillator and the radioactivity was measured by Aloka LSC 502 scintillation counter. In the cases of liver, kidney, gut materials, and muscle, the residual supernatant was evaporated to dryness below $40^{\circ} \mathrm{C}$, re-extracted with a small volume of 
(I) RFP, $100 \mathrm{MHz}$

(II) $\mathrm{ADP}, 60 \mathrm{MHz}$ solvent, $\mathrm{CDCl}_{3}$ referent, TMS sensitivity, $8 \times 10$ sweep time, 400 seconds time constant, 0.1 second
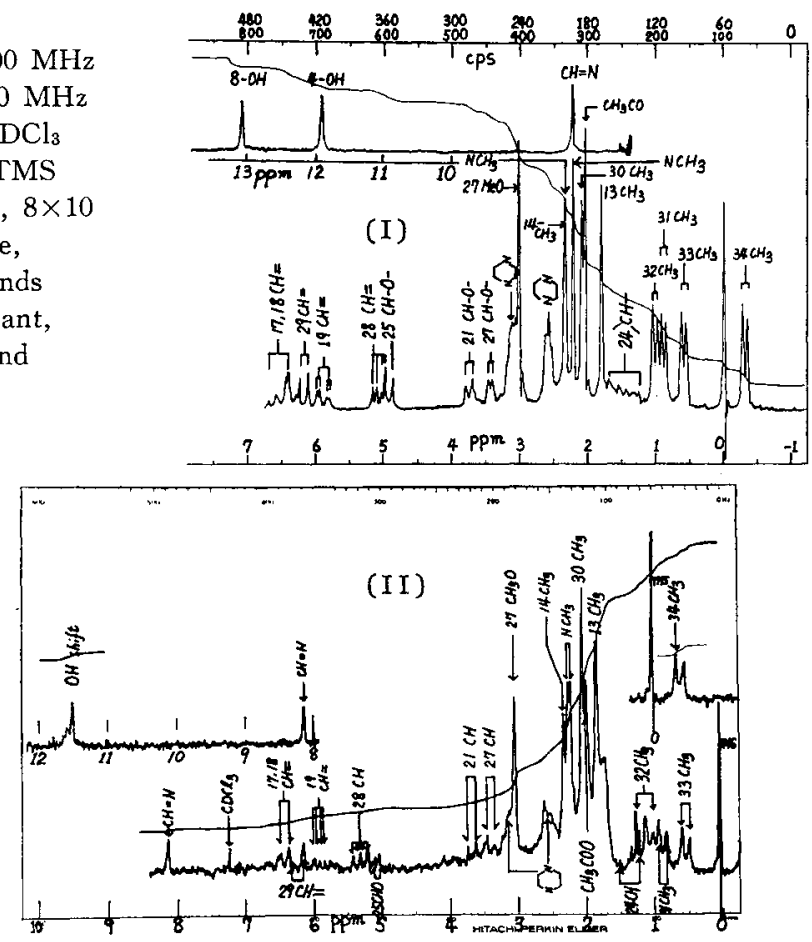

Fig. 1. NMR Spectum of ADP Compared with That of RFP

$\mathrm{Me}_{2} \mathrm{CO}$, and centrifuged. A portion of the supernatant was developed on TLC and the metabolites were examined by scraping off the silica powder on TLC plate.

The adsorption of RFP series on calf serum was examined as follows: $2.5 \mu \mathrm{Ci}$ of each ${ }^{14} \mathrm{C}$-labeled standard material/EtOH was nearly dried in vacuo and it was mixed with 2.5 $\mathrm{ml}$ of calf serum. After the incubation at $37^{\circ} \mathrm{C}$ for $30 \mathrm{mins}$., it was developed through Sephadex G 200 (particle, size, medium; column size, $3 \times 30 \mathrm{~cm}$ ) with $0.001 \mathrm{M} \mathrm{Na-K}$ phosphate buffer, pH 7.55 containing $0.9 \% \mathrm{NaCl}$. Except the case of ${ }^{14} \mathrm{C}-\mathrm{RFPQ}, 0.05 \%$ ascorbic acid was further added to the developing buffer. A portion $(0.2 \mathrm{ml})$ of each effluent $(5 \mathrm{ml})$ was used for measureing the radioactivity by liquid scintillation counter.

4. Color densitometry. Ozumor 82 densitometer was used.

\section{Results and Discussion}

1. Presumable position of conjugation. Coincident with the lack of 4-OH peak of ADP by NMR, ADP was far stable than RFP and the oxidation to its quinone form could not be detected by the usual quinone formation procedure. Thus, masking at 4-OH of RFP by Ad radical was apparent. Besides the synthesis of $A D P$, the reaction of DARFP and Ad or smaller radicals such as nicotinyl was examined. Different from the case of ADP, the reaction of $\mathrm{AdCl}$ and DARFP produced two main pigmental belts by both of developments through Sephadex LH-20 with $\mathrm{CHCl}_{3}$-EtOH $(2: 1)$ and on Kieselgel TLC plate with $\mathrm{CHCl}_{3}$. 
MeOH $(9: 1)$. The Rf values in the latter method were 0.91 and 0.80 while DARFP was 0.69 though the complete isolation of these orange yellew products could not be achieved. The reaction of nicotinyl chloride and DARFP produced six pigmental belts other than DARFP and DARFPQ, when the crude products were developed by the former method. On the other hand, the reaction of RFP and 4-acetoaminobenzene sulfonylchloride(ABSCl) produced the chromatogram quite resemble to that by the reaction of $\mathrm{ABSCl}$ and DARFP, suggested the compulsory introduction of ABS radical to RFP. In RFP skeleton, there is a steric hinderance among 23-OH in macrolide ring and $1-\mathrm{OH}$ in naphthol ring and an electric disturbance among 8-OH in naphthol ring and 1-OH (peri-effect). Therefore, the introduction of Ad radical into the space surrounded by both of macrolide and naphthol rings may be disturbed stereochemically because Ad is known to be the representative tetrahedral structure. While, 4-OH in the naphthol ring and 25-OH (DARFP) are stereochemically indifferent from any other part of RFP structure. The production of two main pigmental belts in the case of AdCl-DARFP reaction might be caused by the lack of acetyl radical at $25-\mathrm{OH}$, suggesting the introduction of $\mathrm{Ad}$ to $25-\mathrm{OH}$ in addition to $4-\mathrm{OH}$. In the case of smaller radicals such as nicotinyl, the introduction into the space such as $21-\mathrm{OH}$ may be far easier thus many products were occured and the individual isolation of them became difficult. In the same time, the compulsory substitution of ABS radical for acetyl of 25 positon was associated. Therefore, when standing on the stereochemical view, the probable first position of RFP to be easily conjugable in vivo is presumed to be 4-OH.

2. Whole body autoradiography. According to the mutual difference in specific activities of ${ }^{14} \mathrm{C}$-labeled standard materials, the dosage of every standard material was mutually different such as $1.5 \mathrm{mg}$ (RFP), $1.8 \mathrm{mg}$ (DARFP), $2.9 \mathrm{mg}$ (RFPQ), and $4.2 \mathrm{mg}$ (ADP) per $5 \mu \mathrm{Ci}$ to each mouse.

RFP : The enough whole body distribution could be seen only at 1 hour after the oral dose. Already at 4 hours, the radioactivity was localized to hepatic area alone. However, even after 12 hours, this localized distribution continued. After 24 hours, the radioactivity in gut materials seemed to be higher than that in the liver. In the case of 4 hours' rat autoradiogram, it was also found to be localized to entero-hepatic area.

DARFP: Throughout the slices at $1,4,7.5,12$, and 24 hours, the radioactivity was found to be localized to the entero-hepatic area alone.

RFPQ: Caused by the shortage of ${ }^{14} \mathrm{C}-\mathrm{RFPQ}$, the number of mice used were necessarily restricted to only two. The radioactivity localized to entero-hepatic area apparently continued from 4 to 12 hours.

ADP : The process of radioautograms from 1 hour to 24 hours was resemble to that of DARFP cases.

3. Radiochemical analysis. As shown on Fig. 2., DARFP rapidly diminished in the liver. The poor distribution of ADP suggested the low absorption from the gut.

Since numerous reports were published concerning the metabolism of $\operatorname{RFP}^{4,5)}$ the interesting findings alone are summarized in Fig. 3.

The total recovery rate, especially the urinary one during 24 hours is known to be gene- 


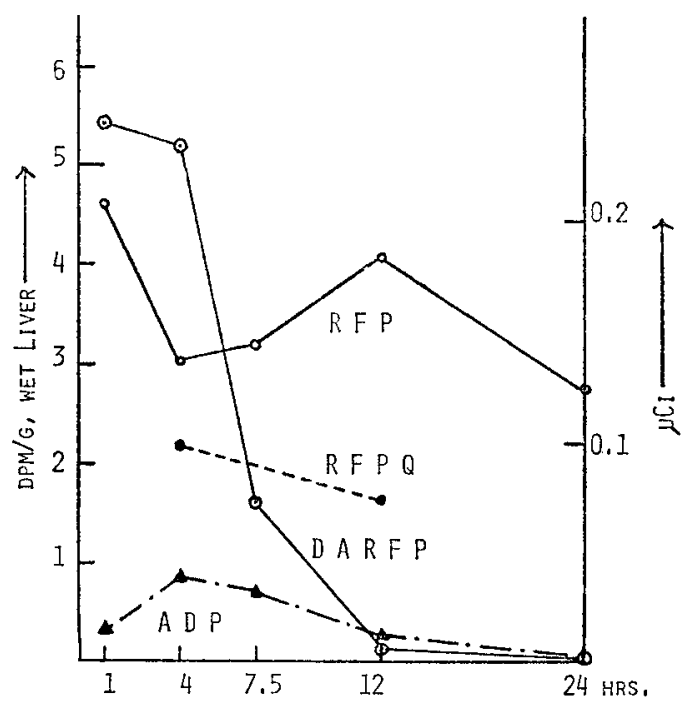

Fig. 2. Prosperity and Decay of Radioactivity in the Liver Autopsied from Residual Frozen Blocks of Mice after the Dose of Respective ${ }^{14} \mathrm{C}$-labeled Standard Materials
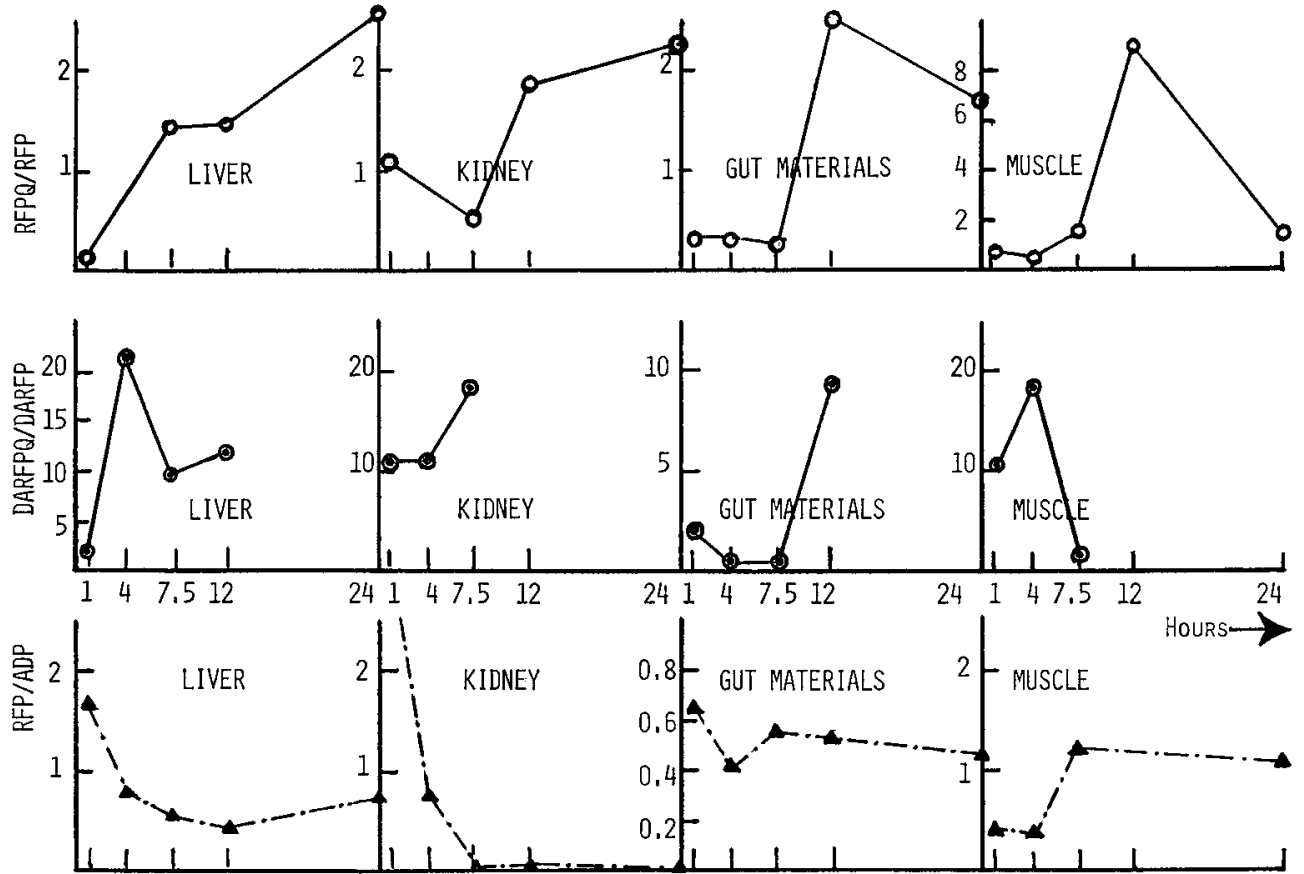

upper rank: the change in RFPQ/RFP rate of RFP group with the lapse of time middle rank: the change in DARFPQ/DARFP of DARFP group

lower rank: the change in the isolation of RFP from ADP (RFP/ADP) of ADP group

Fig. 3 A Result of Radiochemical Analysis of some Biological Materials Autopsied from Residual Frozen Blocks of Mice

rally low in the case of RFP. However, throughout the radiochemical analysiss, the urinary/fecal recovery rates were presumed to be lower in RFP analogues than in RFP. This 
tendency was especially marked in ADP case. From Eig. 3., it may be suspected the followings.

a) The content ratios of RFPQ and DARFPQ increased with the lapse of time, gradually in the liver and since 7.5 hours in the gut.

b) The quinone formation of DARFP group was more predominant than that in RFP group.

c) RFP can be freed from ADP in vivo. However, since 7.5 hours, the increase of freed RFP could not be detected apparently, suggesting also the low absorption of ADP.

4. Inhibitory effect of protein on the oxidation of RFP to RFPQ. This effect had already been suspected when RFP was incubated with a cell-free extract of NQ bacilli, in order to examine the desacetylation of RFP by bacteria. Such a desacetylation could not be detected but the marked inhibition to the oxidation was observed ${ }^{6}$. Indeed, merely a part of RFP can be changed in vivo into RFPQ. It may be caused by the action of various reductases as if equilibrating to the oxidation. However, in spite of the finding that RFP is rapidly oxidized in hydrophilic media without ascorbic acid especially under electrophoresis ${ }^{6}$, the fact that it can be preserved comparatively in calf serum was also experienced. Then the reduction of RFPQ by cysteine as a model of $\mathrm{SH}$ terminal residue of protein was examined. The solution of RFPQ $(500 \mu \mathrm{g} / 20 \mathrm{ml}$ of $0.1 \mathrm{M}$ phosphate, $\mathrm{pH} 7.0)$ was mixed with $500 \mu \mathrm{g}$ of cysteine $/ 20 \mathrm{ml}$ of $0.1 \mathrm{M}$ phosphate, $\mathrm{pH} 6.0$ and the mixture was quickly extracted with $\mathrm{CHCl}_{3}$ after 15 seconds or 5 minutes.

After the evaporation of solvent in vacuo, the residue was developed on TLC and scannered colorimetrically. As shown on Fig. 4., about half of RFPQ reduced to RFP within 15 seconds can be seen. After 5 minutes, the reduction to RFP was found to be complete. On the other side, the heat sterilization completely changed RFP into RFPQ. Therefore, numerous reports concerning the antibacterial effect of RFP may inform us of RFPQ effect. Naturally, there are various substances in vivo, for example, such as those capable of accelerating the oxidation of $\mathrm{RFP}^{7}$ while it is difficult to isolate the completely pure RFP even in vitro. But this finding may give us an explanation for only partial oxidation of $\mathrm{RFP}$ in vivo.

5. Adsorption of RFP series on calf serum. Similarly to the case of WBARG, $\mathrm{mg} \%$ of each standard material to be adsorbed was mutually different caused by the difference of specific activities, $30 \mathrm{mg} \%$ (RFP), $36 \mathrm{mg} \%$ (DARFP), and $58 \mathrm{mg} \%$ (RFPQ). Since the specific activity of RM-AF could not be determined caused by the deficiency, it was adsorbed merely standing on the radioactivity alone $(2.5 \mu \mathrm{Ci})$. As shown on Fig. $5(\mathrm{a}$, b), all of examined RFP series were adsorbed on the first protein fraction which contains mainly IgM. Nakagawa had reported the following four points ${ }^{8)}$; (i) RFP was presumed to be adsorbed on $\beta$-globulin. (ii) It was suggested that DARFP adsorbs additonally on $\alpha_{2}$-globulin. (iii) The protein component affinitive to RFPQ could not be found out. (iv) RM-AF adsorbed tightly to albumin. These findings were mainly based on paper electrophoresis where protein molecule is polarized. While in the case of molecular filtration, since the serum is diluted by a large volume of buffer, the weak bondage is freed and the tight 

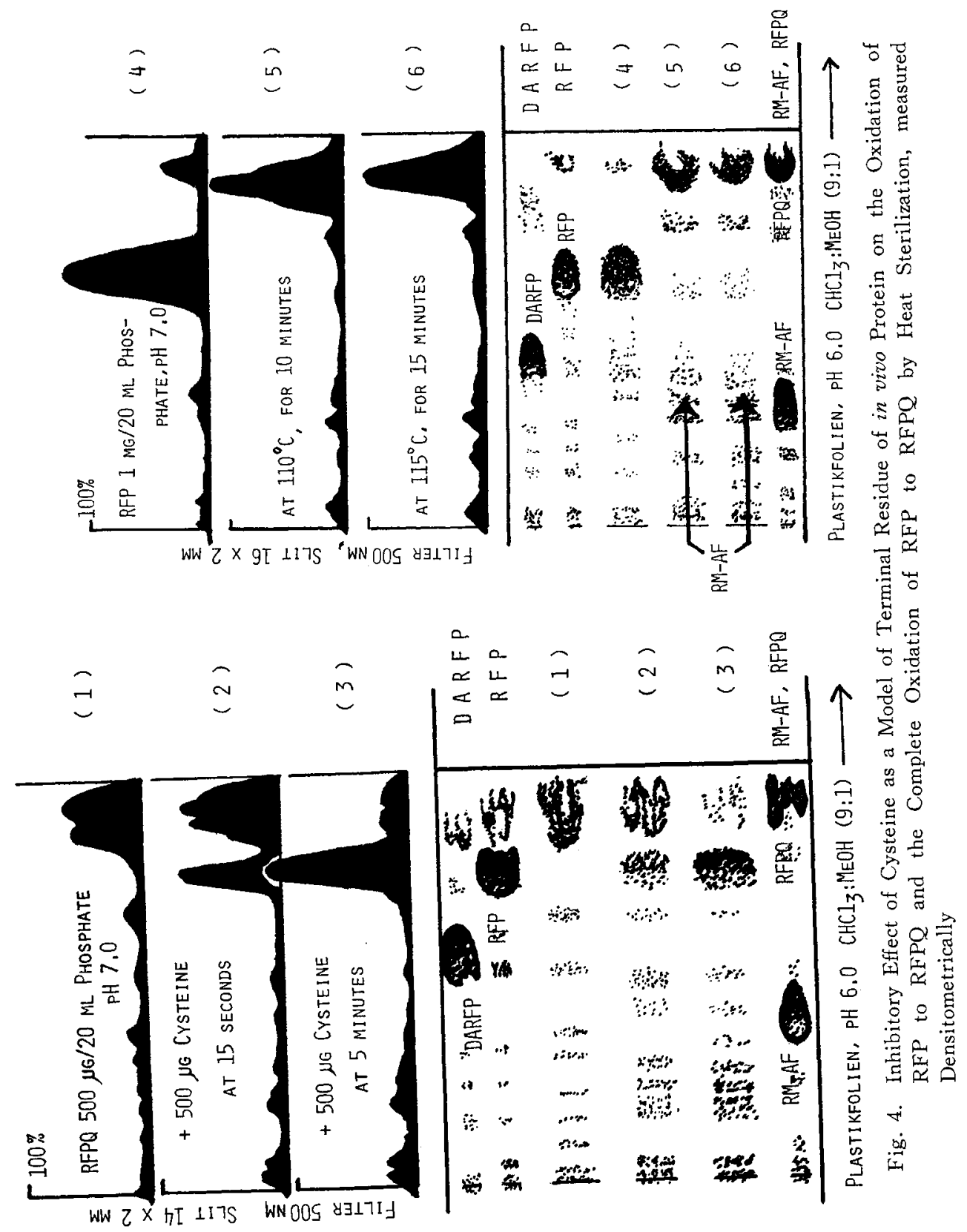


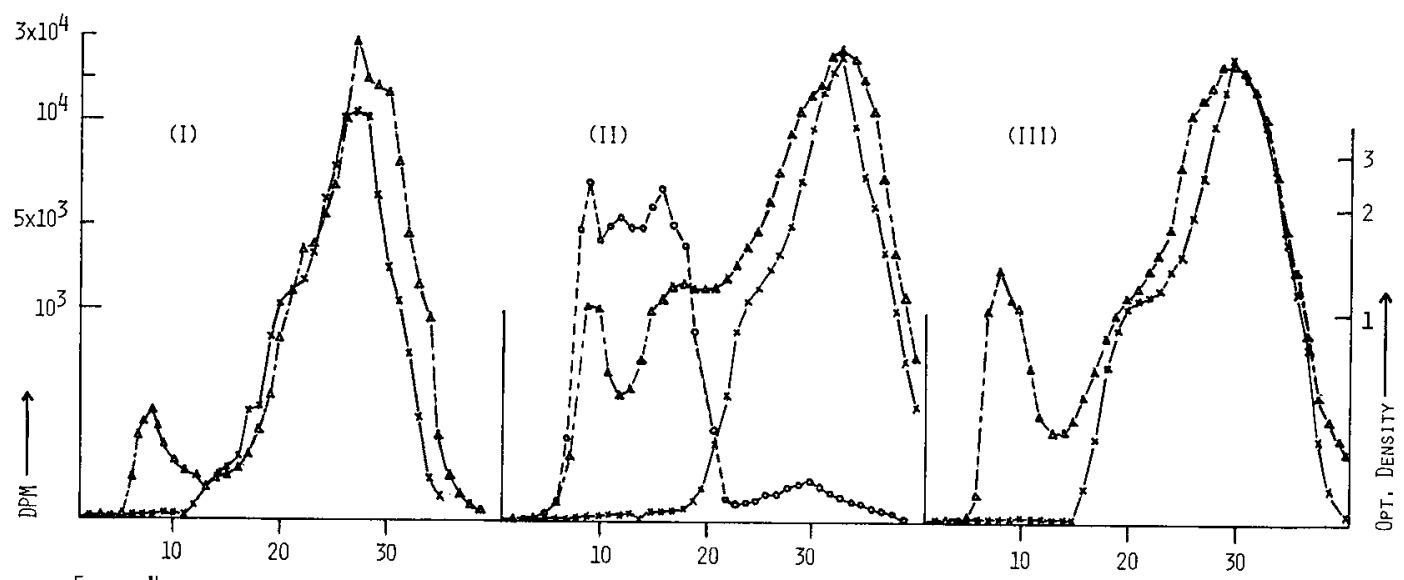

FRACT, No,

Fig. 5. Adsorption of RFP Series of Calf Serum Examined through Sephadex G-200 Column

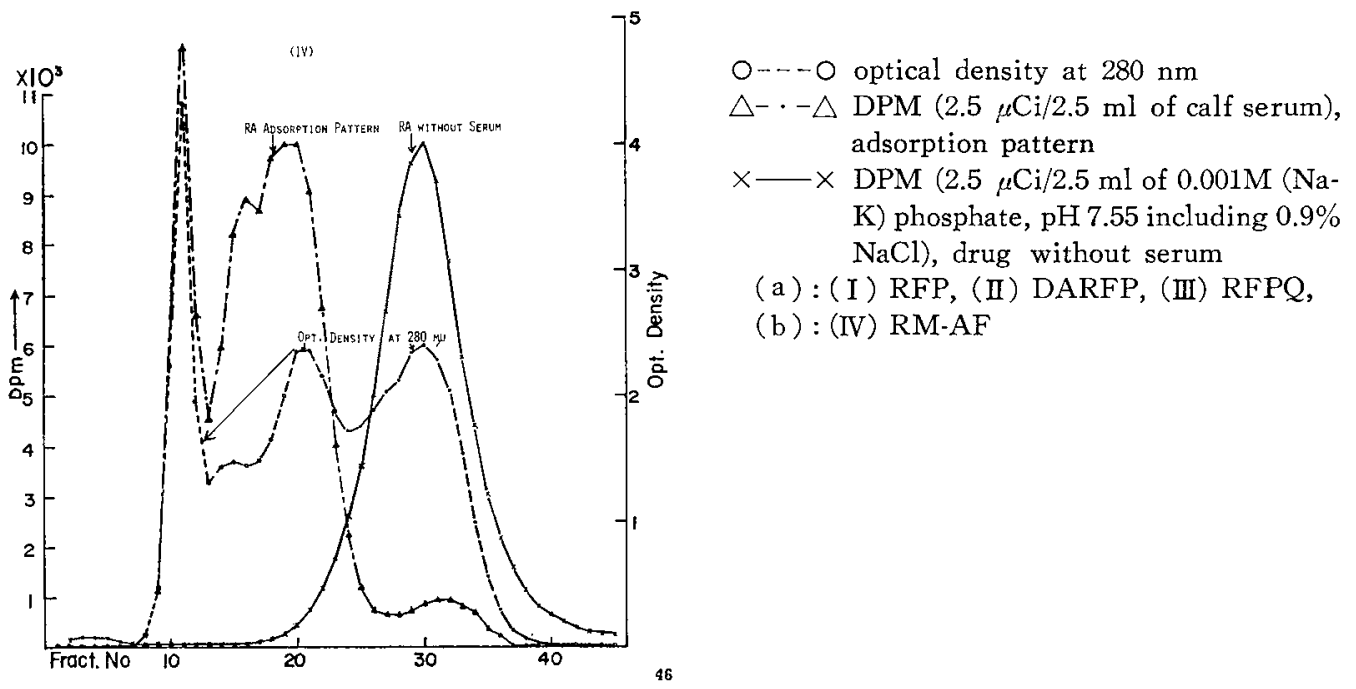

adsorption alone can remain and is detected. Since the first protein fraction includes both of $\alpha$ - and $\beta$-globulin in a rate of $\alpha \gg \beta$ at its peak, this result is never contradictory to (i) and (ii). However, since RFPQ is liposoluble more than DARFP and even than RFP, and generally quinones are known to be the substances tightly adsorbing on protein, the result (iii) seems to be exceptional or even contradictory. For example, the increases in RFPQ/ RFP and DARFPQ/DARFP with the lapse of time mentioned in 3 . suggest us the tight binding of quinones to biological materials. Contradictory to the result (iv), RM-AF was found to adsorb covering all of three protein fractions in this experiment. Since the radiochemical method is the most reliable one in this kind of experiment, the adsorption patterns of RFP series may be concluded by this result.

6. Inhibitory effect on the growth of leprosy bacilli in the footpad. A suspension of 
Table 1 Inefficacy of ADP and RFPQ on the Growth of Leprosy Bacilli in the Footpad

\begin{tabular}{|c|c|c|c|c|c|}
\hline Drug & $\begin{array}{c}\text { Drug } \\
\text { Content }(\%)\end{array}$ & at 15 & 17 & 20 & 25 weeks \\
\hline - & - & $42^{*}$ & 115 & 716 & 238 \\
\hline $\mathrm{ADP}$ & 0.005 & 6 & 39 & 64 & 183 \\
\hline$\prime \prime$ & 0.0005 & 4 & 42 & 207 & 287 \\
\hline RFP & 0.005 & 0 & 0 & 0 & 2 \\
\hline " & 0.0005 & 0 & 0 & 3 & 4 \\
\hline (Exp. 2.) & & at 15 & 18 & & 22 weeks \\
\hline- & - & 83 & 440 & & 111 \\
\hline RFPQ & 0.0005 & 48 & 51 & & 403 \\
\hline RFP & 0.0005 & 8 & 11 & & 680 \\
\hline
\end{tabular}

* Numericals indicate AFB/100 microscopical fields and when they are multiplied by $2.5 \times 10^{4}$, they indicate all of AFB in each footpad.

leprosy bacilli (Raisl P, $0.6 \times 10^{4} / 0.1 \mathrm{ml}$, saline) was subcutaneously injected to each hind footpad of mouse (dd/SPF, male, at 4 weeks after the birth, 12 mice per group). The drugs (ADP, RFP) were dosed for 9-13 weeks. While in another experiment, Raisl P strain of $6.3 \times 10^{4} / 0.05 \mathrm{ml}$ saline suspension was transmitted to every hind footpad and the drugs (RFPQ, RFP) were dosed for 8-11.5 weeks. In all cases, six footpads out of three mice were pooled and examined microscopically. The results are summarized in Table 1.

It was found that not only ADP but RFPQ is ineffective at this dosage.

7. Discussion. Since RFPQ alone emitted the weak fluorescence $\left(20 \mu \mathrm{g} / \mathrm{ml}\right.$ in $\mathrm{CHCl}_{3}$, at $410 / 520(\mathrm{~nm} / \mathrm{nm}), 47$ units (slit 10/7)) among RFP series, the tracer method or the spectrophotometry9' seems to be the most reliable determination method of them. The masking of RFP chromophor (naphthol ring) selectively at its 4-OH by $\mathrm{AdCl}$ brought about a marked hypsochromic shift (to $425 \mathrm{~nm}$ ) and produced ADP which was very liposoluble but unexpectedly very low absorptive derivative of RFP. This poor in vivo distribution which was localized even more than DARFP may be caused by its too much high molecular weight. Thus, it was ineffective on leprosy bacilli similarly to RFPQ by mouse level experiment, which distribution was also localized to enterohepatic area alone as well as DARFP. As the result, a seris of reactions among RFP or DARFP and carboxylic acid chlorides of higher or lower molecular size could not bring about any preferable result to develop a promising derivative superior to RFP but were merely useful for presuming the probable position of conjugation in RFP skeleton. The result of radiochemical analysis of excreted RFPG from rat by benzyl alcohol extraction method was published to other report. ${ }^{10}$ The important fact was that the enough whole body distribution could be noticed only in 1 hours' radioautogram of RFP group alone and throughout the other groups (metabolite-groups) the poor distributions localized to entero-hepatic area were found even at 1 hour' ones. Similarly to this kind of localized distribution of general macrolide antibiotics including Rifamycins, 
the weak point of RFP can not be avoided except very short term in vivo. Even though nearly all of usual metabolites of RFP possess their antibacterial effects comparable to RFP itself, this result proves the uselessness of these metabolites including DARFP. Amongst RFP series, RM-AF alone is weakly acidic and all of the others are basic substances. The adsorption of RM-AF very tightly to calf serum suggests us a presumption that the content of RM-AF will gradually increase among metabolites remaining in tissue and organs. While, it is well known fact that p-quinones are stable more than the corresponding p-diphenols and the reduction of the former is more resistant than the oxidation of the latter. For example, the formation of RFP from RFPQ could not be detected when the urinary specimen pooled from mice of RFPQ group was analyzed. In other word, the auto-oxidation of RFP and DARFP to the respective quinones can not be disregarded even under co-existence of biolological materials. However, since all of the biological specimens were treated immediately under same condition and as shown on Fig. 3. DARFPQ/DARFP were much higher than the corresponding RFPQ/RFP, DARFP which is more hydrophilic than RFP was thought to be easily oxidable more than RFP in addition to the finding that the contents of quinone-forms gradually increased in gut materials. As for urinary and fecal recovery rate, a specially devised glass apparatus was used and the urinary/urinary+ fecal ratios (\%) after 24 hours were 31.5 (RFP), 2.7 (DARFP), 3.5 (RFPQ), and 10.6 (ADP). This fact also indicates the predominant fecal excretion of quinone-forms similar to DARFP. Summarizing these results, it may be suspected that if a quinone of formyl-type is metabolized by demasking of piperazine side residue as in the case of freed RM-AF it may most tightly adsorb on biological materials and remain for long-term in vivo. Therefore, the in vitro hydrolysis of RFPQ was examined according to the acidic hydrolysis of RFP to produce RM-AF. However, on the resultant chromatogram, a slight spot of RM-AF alone could be detected and most of RFPQ changed into impure materials ${ }^{11)}$. Through analysis of urinary metabolites of RFPQ group, a notable amount of DARFPQ was detected by radiochemical scan of TLC plate when it was developed by $\mathrm{n}-\mathrm{PrOH}-\mathrm{CHCl}_{3}$-Dioxane $(1: 3: 1)$ saturated with $0.1 \mathrm{M}$ phosphate, $\mathrm{pH} 6.5$ and by $\mathrm{CHCl}_{3}$-Dioxane-MeOH $(1: 3: 1)$. Therefore, the in vivo desmethylation is possible even in the case of quinone form. Contrary to the anxiety about the possible antigenicity of RM-AF and quinone-forms, the immunosuppressive effect has been reported ${ }^{12-14)}$. Kasik, et $a l .{ }^{15)}$ reported that the main substance which causes immunosuppression is RM-AF when examined by PHA-induced blast formation. Although RM-AF binds probably to polysaccharides which can be associated by its tight binding to dextran sulfate and so the possible non-specific influence must be considered in the case of in vitro experiment, the accelerative effect of RFP on the progress of immunological disorders in leprosy patients must not be neglected when remembering the mechanism of action of RFP as an inhibitor of protein chain initiation and elongation through inhibition of RNA polymerase. The other important problem is the side action of RFP on gastro-intestinal tract.

It is well known fact that enterobacteria are living in vivo anaerobically ${ }^{16)}$. Several 
authors reported ${ }^{16,17)}$ that RFP and Clindamycin (CLM) are highly effective on bacteroides. CLM is known to be an antibiotics increasing the action area by its in vivo desmethylation. It was re-examined by using Bact. fragilis $\left(3.8 \times 10^{4,6}\right.$ microbes) and Bact. dystasonis (2.9 $\times$ $10^{4,6}$ microbes) to each $5 \mathrm{ml}$ of semi-liquid GAM. After incubation at $37^{\circ} \mathrm{C}$ for 48 hours in Gas-Pak the completely inhibitory molecular concentrations were:

Bact. fragilis $\left(3.8 \times 10^{4}, 3.8 \times 10^{6}, \times 10^{-6} \mathrm{M}\right) ; \operatorname{RFP}(6.15,6.15), \operatorname{CLM}(55.5,55.5)$, U-24729 A (N-desmethyl pentyl CLM, 500, 500), Homosulfamine $(167,500)$, B $663(167,167)$, DDS and Ciba 1906 (>500, >500). Bact. dystasonis $\left(2.9 \times 10^{4}, 2.9 \times 10^{6}, \times 10^{-6} \mathrm{M}\right) ; \operatorname{RFP}(6.15,18.5)$, CLM and U-24729 A (6.15 6.15), Homosulfamine (both incomplete at 500), B $663(55.5$, 167), DDS ( $>500,>500)$, Ciba 1906 (both incomplete until 167).

This result reminds us of the significance of nutritional state during RFP therapy. RFP was effective even on ophthalmic leprosy ${ }^{18)}$ and detected even in peripheral nerve ${ }^{192}$. However, when considering its weak point as a sort of macrolide-type antibiotics, a rational combined therapy such as alternative form will further be necessary for both preserving drug action constantly and minimizing the dosage.

The authors are gratefel to Dr. K. Ueno of Medical Department, Gifu University for supply of Bacteroides strains. They are also indebted to all of Dr. K. Akimoto and other members of Daiichi Pharmaceutical Company for NMR, elementary analysis, and supply of ${ }^{14} \mathrm{C}-\mathrm{RFP}$, and of Nippon Upjohn Company for supply of Clindamycin and U-24792 A. The mouse footpad experiments were cooperated by Dr. K. Nakamura and Miss Y. Yogi of Laboratory of Animal Care in this Institute.

\footnotetext{
Abstract

Metabolism of RFP and of the representative metabolites was individually compared by tracer method.

1. The results were discussed especially concerning the metabolites remaining for long-term iu vivo.

2. A new derivative of RFP named as ADP was synthesized. Through the similar reaction between RFP or DARFP and aromatic or alicyclic carboxylic acid chloride the presumable position in RFP skeleton of conjugation such as glucuronide conjugation was discussed.

3. In vivo inhibitory effect of protein on the oxidation of RFP series to their respective quinone-forms was examined using cysteine as a model of in vivo $\mathrm{SH}$ residue.

4. The predominant adsorption of RFP series on IgM of calf serum was concluded.

5. The low efficacy of RFPQ and ADP on the growth of leprosy bacilli was concluded by mouse footpad method. The uselessness of DARFP was also presumed.

6. The antibacteroidal effects of RFP was compared with those of some antileprosy drugs and the influence of RFP on in vivo enterobacteria was mentioned.

7. The relation between these findings and RFP therapy was discussed.
} 


\section{References}

1) S. Tsutsumi, M. Gidoh, M. Narita, S. Koide, and T. Funadzu: On characteristic antiinflammatory effects of several antileprosy drugs. The U.S. Japan Cooperative Medical Science Program, the 12th Joint Conference on Leprosy, (1977).

2) S. Tsutsumi, Y. Sakamoto, and M. Gidoh: Pharmaceutical view of Rifampicin. La Lepro, 43, 1-7 (1974).

3) H. Nakagawa and M. Sunahara: A new Rifampicin metabolite found in human urine. Rinshō Yakuri, 3, 305-307 (1972).

4) K. Akimoto, K. Ono, and Y. Nanpo: Absorption, distribution, metabolism, and excretion of Rifampicin (RFP) in the rat. Jap. J. Antibiotics, 23, 250-256 (1970).

5) G. Binda, E. Domenichini, A Gottardi, B. Orlandi, E. Ortelli, B. Pacini, and G. Fowst: RFP, a general view. Arzneimittelforsch., 21, 1907-1977 (1971).

6) S. Tsutsumi, Y. Sakamoto, M. Gidoh, and S. Hazama: Trials for analyzing pigmental antileprosy drugs. The 20th Eastern Meeting of Japan Leprosy Association, (1971).

7) H. Nakagawa, M. Machida, and M. Sunahara: On naphthohydroquinone dehydrogenase in human saliva. Proceedings of the symposium on chemical physiology and pathology, 10, 196-204 (1970).

8) H. Nakagawa: On the binding of Rifampicin on serum protein. Rinshō Yakuri, 2, 362-364 (1971).

9) H. Nakagawa and M. Sunahara: Metabolism of Rifampicin in the human body (the 1st report). Kekkaku, 48, 167-176 (1973).

10) H. Nakagawa, M. Sunahara, and S. Tsutsumi : A hydrophilic metabolite of RFP. Chemotherapy, 21, 1916-1917 (1973).

11) S. Tsutsumi, Y. Sakamoto, and M. Gidoh: Acidic hydrolysis of RFPQ as the model of a possible in vivo metabolic pathway. LSM., 621 (1974).

12) D. C. Graber, J. Jebaily, R. L. Galphin, and E. Doering: Light chain proteinuria and humoral immunoincompetence in tuberculous patients treated with Rifampin. Amer. Rev. Resp. Dis., 107, 713-717 (1973).

13) K. Nessi, R. Pallanza, and G. Fowst: Rifampicin and immunosuppression. Arzneimittelforsch., 24, 832-836 (1974).

14) S. Gupta, M. H. Grieco, and S. Siegel: Suppression of T-lymphocyte rosettes by Rifampicin. Studies in normals and patients with tuberculosis. Ann. Int Med. 82, 484-488 (1975).

15) J. E. Kasik, M. Monick, and J. S. Thompson : Personal Communication.

16) X. Morishita and T. Mitsuoka: Antibody responses in germ-free chickens to bacteria isolated from various sources. Japan. J. Microbiol., 17, 181-187 (1973).

17) S. M. Finegold : Antimicrobial therapy of anaerobic infections. Chemotherapy 21, 1326-1329 (1973).

18) Cooperative Research Team on Chemotherapy of Leprosy among National Leprosaria in Japan : Therapeutic effect of RFP on leprosy. I. clinical effect. La Lepro, 43, 8-25 (1974).

19) A. C. McDougall, J. A. Rose, and D. G. Graham-Smith: Personal Communication. 


\title{
Rifampicin (RFP) 代謝の基礎的研究
}

\author{
儀同政一, 坂本芳幹, 堤 貞衛 \\ (国立多摩研究所) \\ 中川英雄 \\ (国立療養所東京病院)
}

RFP ならびにその代表的な代謝物がそれぞれ別個に トレーサー法で代謝を比較された。

1，その結果につき特に体内に承く残留する代謝物に 関し討論された。

2, ADP と名付けられる RFP の新誘導体功合成さ れた。似た様な反応が RFP または DARFP と二三 の芳香属または脂環属カルボン酸クロライドの閣でおこ なわれ，それを通じて，グルクロン酸抱合の様な抱合が RFP 骨格中どこで起るかが推定され，討論された。

3, RFP 類がそのキノン体へ酸化される場合に, そ
れへの生体蛋白阻止作用がシステインを体内 SH 残基の モデルとして試験された。

4, RFP 類が主に仔牛血清 $\operatorname{Ig} M$ 八吸着することが 結論された。

5, らい菌増殖への RFP キノンと ADP の阻止作 用は足蹠法によると弱く, DARFP も有用でないこと が推定された。

6, RFP の antibacteroidal 効果が若干の治らい薬 と比較され，RFP の腸内細菌への影響が述べられた。

7, これらの所見亡 RFP 治療の関係が討論された。 